\title{
REVIEW ARTICLE: \\ THE DELIVERANCE OF GOD: AN APOCALYPTIC REREADING OF \\ JUSTIFICATION IN PAUL BY DOUGLAS A. CAMPBELL
}

\author{
Bruce Clark
}

\section{Summary}

Campbell launches a sustained attack against traditional theological conceptions of justification and aims to free Romans 1-4 (on which these conceptions seemingly rest) from a widespread rationalistic, contractual, individualistic (mis)reading, which gains its plausibility only by the modernistic theological superstructure forced upon it. Campbell then presents an in-depth re-reading of Romans 1-4 (as well as parts of chs. 9-11, Gal. 2-3, Phil. 3), in which Paul engages in a highly complex, 'subtle' polemic, creatively employing 'speech-incharacter' as a means of subverting a Jewish Christian 'Teacher' whose visit to Rome threatens to undermine the Roman Christians' assurance of salvation. Campbell argues that justification is participatory and liberative: Christ's death and resurrection constitute the 'righteousness/deliverance of God', by which he justifies, or delivers, an enslaved humanity from the power of sin. This article concentrates primarily on Campbell's own exegesis, concluding that, while important aspects of Campbell's critique of both "justification theory" and traditional readings of Romans 1-4 must be carefully considered, his own exegesis is not only ingenious, asking too much of Paul and the letter's auditors, but altogether untenable at key points.

\section{Introduction}

If one desires to have one's articulation of justification in Paul put to the test, The Deliverance of God is the book to read. ${ }^{1}$ Campbell surveys

${ }^{1}$ Grand Rapids: Eerdmans, 2009. 
the battle-his controlling metaphor-between, on the one hand, New Perspective advocates and other revisionist readings of Paul, and, on the other, recent defenders of traditional readings of justification, and employs critiques from each side to cripple the other (while adding his own). Returning to Romans $1-4$, he begins the exegetical task afresh, though undoubtedly inspired by the works of K. Barth, J. Torrance, K. Stendahl, and S. Stowers. After identifying parts of the text as logically or theologically incoherent, he then restores coherence by (1) placing those parts in the mouth of an opposing 'Teacher' (who previously troubled Galatia and Antioch, originating in Jerusalem) and then by (2) viewing the rest of Romans 1-4 as compact, muted, and anticipatory expressions of the full-orbed, unabashedly apocalyptic material of chapters 5-8. Therefore, Campbell's bone to pick with the traditional readings is primarily at the argumentative, not the exegetical, level (n. 7, p. 529/1076): e.g. traditional interpreters have rightly understood what Romans 1:18-32 says but, critically, not who is saying it.

Why are the truly Pauline portions of Romans 1-4 only muted apocalyptic expressions? Having never visited Rome and uncertain if this Teacher had arrived, Paul must carefully win over the Romans. So he first employs terminology and concepts from both the earliest Christian tradition and the Teacher's own discourse; the former Paul subtly bends to reflect his own views (707); the latter he completely subverts (547). What is Paul's overarching goal? While the letter's aim is to champion an impregnable Christian assurance (759), which the Teacher would undermine, within chapters 1-4 'Paul's argumentation is primarily negative' (603), and 1:18-3:20 serves to 'confound the Teacher, and largely in terms of the Teacher's own initial assumptions' (529, his italics). How so? 'The Teacher's implicit commitment to desert [set forth in 1:18-32] is...turned against him [in 2:1]' (574), in a way that undermines his own 'gospel', which Campbell summarises in the first person as follows: 'turn (to circumcision and the Jewish law) or burn; only circumcision of the body and heart will allow you to act righteously and so obtain a final verdict from God of rectitude that leads to salvation' (n. 107, p. 568/1087).

What is Paul's own constructive thought in chapters 1-4 (primarily reflected in 1:16-17; 3:20-26, importantly, verse 28; polemically, 4:222; straightforwardly, vv. 23-25)? Christ's faithfulness-i.e. the sum of his redemptive work - climactically discloses God's righteousness, the 
'decisive saving and delivering act of power by God, the divine King' (699). Whoever is characterised by faith/faithfulness is freely 'justified' (= 'delivered') or credited with 'righteousness', or divine salvation. Therefore, justification in Paul is anything but an inert 'legal fiction' granted by an indifferent 'God of retributive justice', who unfairly requires a volunteerist faith from a humanity that is somehow ethically both incapacitated and culpable. Rather, justification is a decisive, ontologically-transformative act of deliverance by an everbenevolent divine monarch for a hopelessly enslaved humanity. Claiming to be truest to Luther, Campbell champions a justification that actually 'justifies-i.e. delivers - the ungodly' (4:5). This in nuce is Campbell's 1218-page tome The Deliverance of God (hereafter $T D o G)$. In general Campbell is spirited, candid, pulls no punches, betrays sincere ecclesiastical concern, and is well aware of just how high the stakes are. His interests are hardly antiquarian.

\section{Laying Siege to the Citadel of 'Justification Theory'}

The first 466 pages are largely negative. A critical move in his overall argument is to characterise traditional readings of justification as instantiations of a single comprehensive soteriological system, or 'Justification theory' (hereafter J-theory). J-theory posits (1) an indifferent, omnipotent deity, whose nature and ethical demands are known to all humanity (but especially to Jews via Scripture) and whose judgements are according to desert; (2) a rational, self-interested, ethically inadequate, culpable humanity who either ignores that inadequacy (and receives just punishment) or, upon honest reflection, owns it agonisingly and, after receiving new soteriological information, rationally exercises faith in (3) a Christ who suffers God's wrath instead of, and bestows his obedience upon, the believer. Such a move forces advocates of traditional readings to consider the possibility of unseen disturbing implications, exposing an exegetical naïveté that views the debate in terms that are exclusively lexical and syntactical.

What are Campbell's most salient critiques of J-theory (cf. summary on p. 183)? Does it make sense 'to imagine that human wrongdoing is essentially economic in any sense with respect to God-that human sins are a violation of God's rights to certain good and services' (52)? Can J-theory actually point to 'a clear statement [in Paul] that [Christ's] 
atonement is propitiatory, satisfying the just wrath of God with human sins' (712)? Is Paul, like J-theory advocates, 'accustomed to condemning ethical performance and to perceiving repeated failure in relation to it as a healthy thing' (81, his italics; cf. n. 35, p. 83/951)? Is not J-theory at least partly responsible for mass confusion in Protestant circles regarding ecclesiology (84), conversion (cf. 151, ch. 4), and sanctification (cf. his provocative excursus on p. 183)? He sounds Käsemann's concerns regarding the failure of the church before and during WWII Germany (188): does J-theory's individualistic diagnosis and treatment fail to 'provide the resources the church needs for opposing [the systemic] evil that stalks the world'? Also, just as many would accept that a Chalcedonian conception of the phrase 'Son of God' cannot automatically be equated with the phrase 'son of God' in Scripture, could the same be true of J-theory's conceptions of 'works', 'law', or 'righteousness' (243-44)? Chapter 9, which explores 'the peculiarly resonant relationship between Justification discourse and modernity' (284), maintains that such diverse figures as Locke, Kant, Schleiermacher, Bultmann, Billy Graham, and Bill Bright have contributed to and/or propagated a deeply modernist J-theory. Campbell leaves no stone unturned, and J-theory advocates will be impoverished, if not imperilled, by ignoring his critiques.

Some of Campbell's stronger challenges to J-theory's exegesis of Romans 1-4 include: in 1:17 how can it be coherent to understand દ́k

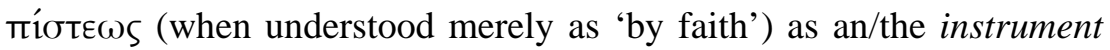
for the revelation of 'the righteousness of God' (377; similarly, for Si⿳亠口冋

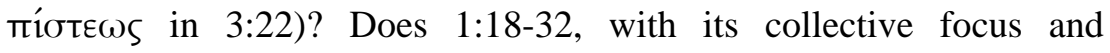
emphasis on complete human incapacity, not contain an 'implicit injustice' if, as J-theory maintains, 'it is an account of individual failure and culpability' (462; cf. 359-60)? Furthermore, have J-theory advocates adequately accounted for the numerous stark stylistic differences in 1:18-32, not to mention its unique intertextuality (360; 533-34)? Is not 2:14-15 still 'an anomalous and unresolved element within the conventional reading' (320)? Are not the revisionists (Stendahl, Sanders, et al.) right to say that if 2:17-29 describes 'a generic Jew', then 'the consequences for Paul's powers of description and argument are dire' (559)? Where in Romans is the demand for moral 'perfection' asserted by J-theory (347)? In 3:25 do conventional

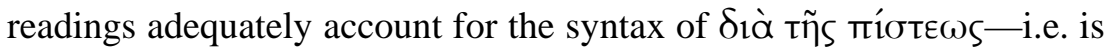
not the rendering 'through faith in his blood' 'both awkward and 
unparalleled in Paul' (380)? In Romans 4 can J-theory advocates coherently explain the relationship between Abrahamic faith in God and Christian faith in Christ (and the transition from one to the other) (390-91; cf. 723)? Similarly, does Romans 4 support J-theory's assumption that faith must be particularly Christian? In Romans 4:23 how does Christ's resurrection 'fit' into the overall argument of chapter 4 (395), for 'the saving function of the resurrection in 4:25 [is] effectively impossible to account for in Justification theory' (754)? Have J-theory advocates supplied a satisfying answer to how Romans 1-4 and 5-8 relate (406)? Does J-theory's principle of sola fide really stand up to scrutiny when ríotss is considered within its context in the Pauline corpus (427-28)? Campbell repeatedly, if unoriginally, contends that the more that J-theory exegesis is detached from its theoretical superstructure and placed squarely within the 'original historical context', the more implausible it is. For how many J-theory advocates (let alone Christian ministers) is the following statement germane: 'It is difficult to think that the original historical situation is important in relation to the exposition of universal evangelical truths' (521)? Finally, in Romans are Paul and his opponents really starting from a similar starting point (i.e. the necessity of performing works of the law) and only then disagreeing about how that necessity should be met, or do they have two completely different gospels (cf. 521)?

But does Campbell's generalisation of traditional readings as a single 'J-theory' come at a price (as some reviews of TDoG maintain)? Campbell first introduces J-theory as a 'thought experiment' (13). The strength of any such experiment is its ruthless logical coherence, and Campbell exploits this in order (1) to strain the 'plausibility structures' of traditional readings and (2) to point the reader to new interpretative possibilities. But as with all such coherentist 'experiments', on their own they remain just that-an experiment, not necessarily a description of the 'outside' world, unlike a description formed from careful analysis of (in this case) scholarship on justification in Paul ( $a$ la Westerholm). One must demonstrate that such an 'experiment' accurately characterises external phenomena. Furthermore, such coherentist experiments, if not open to serious critique/revision, can become notoriously hegemonic, as they magically shed their own cultural origins and provisional perspective (one person's 'self-evident truth' is another's unfounded premise). 
Unfortunately, in TDoG the spirit in which the 'thought experiment' is offered is progressively lost, and it loses its provisionality, ever above critique and always, even deliberately (183) critiquing and trumping (e.g. 266, and more generally in sections 2 and-3 of ch. 8; 313, 331, 346, 347, 376, 386, 388, 395, 463, 818-19, 901-902; note how F. Watson's work defies Campbell's categories in n. 20, p. 420/1043). The question arises: even as Campbell indicts opponents with the charge of epistemological and theological 'foundationalism', does Campbell's J-theory (and his scathing critiques of it) not itself epitomise an unapologetic, unexamined foundationalism? How else is one to account for his contention that traditional readings of justification are necessarily 'emphatically universal and also timeless and generic' (175; cf. 37, 49, 383, 395; n. 162, p. 395/1038, 521), nonpneumatological $(163,210)$, rationalist in (1) their epistemology (e.g. $74,86,163,386)$ and, hence, (2) in their conception of general revelation (39-41, 58; n. 13, p. 74/948; 122, 164, 203-205) and (3) in their implicit endorsement of atheism (204), 'fundamentally sinister' in regard to anti-Semitism (205-206), and conditional in their conception of grace (e.g. 337)? I do not make this charge of foundationalism lightly or merely as an ironic riposte. At the conclusion of Part I, Campbell, having listed the above (and many more) necessary 'difficulties' inherent in J-theory, asserts that there exists 'a causality within these difficulties that is largely self-evident' (218). Really?

We can illumine the foundationalist nature of Campbell's argument by asking either/or questions that problematise the internally coherent nature of his 'thought experiment'. For example, must Christ's death be either satisfactory or liberating and transformative, and must the dominance of the former in Romans 1-4 and of the latter in Romans 58 necessarily create 'framing tensions' (cf. 712)? Must God be either retributive in his justice or benevolent $(664,706)$ ? That is, must God be either one who is 'compassionate, gracious, slow to anger, abounding in love' or one who 'will by no means leave the guilty punished' (Exod. 34:7)? Must God deal with humanity in either strictly individualistic or strictly corporate terms? Must a soteriology of unconditional grace negate an initial response of faith or even a covenantal or contractual arrangement (101)? Must 'belief in the Lord Jesus Christ' be either 'evidence of salvation' or 'its appropriation' (896; cf. 817-20)? 
Campbell should have used the 'thought experiment' for the strengths mentioned above and then selected and engaged with five or six diverse proponents of traditional readings. This misappropriation of a good idea constitutes, for the present reader, one of the most disappointing aspects of the book: at the end of the day, Campbell's 'experiment' advances his argument but at the expense of preventing his provocative thesis from engaging in a more exciting, real dialogue (actual engagement with J-theory readings is surprisingly rare). The work rightly denounces a rationalist epistemology while, unfortunately, leaning upon it to secure its argumentative strategy.

\section{Exegesis}

At bottom Campbell claims that Romans 1-4 has been radically misread. Without marginalising essential theological and hermeneutical considerations, this review will, however, focus on his exegesis: how well does Campbell's alternative work? His re-reading, in large measure, does not so much remedy as avoid the problems of J-theory's exegesis (765). His is an ingenious strategy (cf. his 'basic sketch' on 527; cf. 602; partial summaries of Romans 1:18-3:20 on 528-29, 542, $574,590)$. Critically, we will assume the plausibility of 'speech-incharacter' as a rhetorical device (cf. 530); the proof of the pudding is in the eating.

Like most theories of Romans' occasion, Campbell's (495) achieves only plausibility, but unlike some others it plays a significant role in his exegesis. In short, with 16:17-18 (and 3:8) as a catalyst, he contends that Romans shares mutatis mutandis Galatians' occasion-i.e. hostile countermissionaries, whose arrival in Rome is past or imminent. The challenges to this theory require Campbell to resort to a number of second- and third-order hypotheses. It is unfortunate that this merely plausible theory alone 'opens up possibilities for new detailed interpretive strategies' (511). In short, his construal of the letter's occasion (and, hence, his reading of Romans), requires a low historical view of Acts, a post-Jerusalem Council resurgence of (what has been called) the Judaizing movement, an unfalsifiable historical construction of Paul's biography, and a strong reliance upon a disputed textual portion of Romans 16. Also, his reading requires a subjective reading of ríotıs Xpıбtoũ (cf. 527). 


\subsection{Romans 1:18-32}

Delaying a full consideration of 1:16-17 until 3:20-26, Campbell construes 1:16-17 and 1:18 as in irreconcilable opposition (543): the former speaks of a benevolent God who has 'revealed' his (benevolent) righteousness; the latter, of an angry God who is 'revealing' his wrath. Paul, then, is contrasting 'two gospels' (543). The rá $\rho$ of verse 18 has little/no meaning and 'the shift in the texture of Paul's argument at this point, into the Teacher's voice, would probably have been signaled by an appropriate voice and gesture as well' (n. 61, p. 543/1082). It is unclear how Campbell labels 1:18 a 'gospel' or how from 1:18 it is 'immediately apparent' that the Teacher's gospel 'has no significant input from Christology' (543).

Romans 1:18-32, then, is the Teacher's wrathful 'tirade' that would have been immediately 'repugnant' to its auditors, who would have 'had as little trouble recognizing him as a modern TV watcher would have recognizing a speech containing the word(s) "hi-diddly-ho" as spoken by Ned Flanders' (547). (Flanders is a character on the American animated television show The Simpsons.) Campbell emphasises the 'absence of self-knowledge' (only a third-person 'they') and the 'repugnant tone' of the Teacher's judgements (546, 667). But could the absence of the first person be otherwise explained (e.g. it is an historical account)? And might 1:18-32 not just as easily have been performed with a sober tone?

One of the central reasons why 1:18-32 reflects the Teacher's (and not Paul's) voice is its prospective, rationalistic epistemology that (true to J-theory) holds to 'two root metaphors-a rational, reflective individual ... becoming aware of a just God ... followed by the [former's] realization of wrongdoing' (331). Elsewhere Campbell speaks of how, in the traditional reading, Romans 1:18 will 'presumably serve as a springboard for other assertions, as those godless pagans who are listening, and are persuaded by the truth of the claims, are motivated to take some action to avoid a terrifying future' (358). All this, Campbell avers, is foreign to Paul. But where does 1:18-32 argue that persons must 'become aware' (italics mine) of a just God and come to a 'realisation' of their 'wrongdoing/error'? From verse 18 onward does the text not argue that all are already aware? No such 'realisation' is required. Does the pericope begin with a statement of humanity's ignorance of the truth or of its suppression of the truth? 
But more straightforward are the two following observations. First, one can only begin to think of $1: 18-32$ as containing a prospective epistemology if 1:16-17 comes from another voice; otherwise, the good news has in fact preceded the bad news. Second is an observation that Campbell himself makes of Galatians but not of Romans: Paul 'is writing to converts' (884); he writes to those 'loved by God, called to be saints' (1:7), whose ríotıs is being proclaimed around the world (1:8); he writes not to convert them but to 'strengthen' them (v. 11). Where does Romans suggest its auditors include 'those godless pagans who are listening'? Furthermore, what if the central aspects of Romans 1:18-32 could be found elsewhere in Paul (or in one of his earliest interpreters/imitators)? Within Romans Paul describes his auditors' pre-Christian behaviour as 'offering your members as enslaved to impurity ['ak $\alpha \theta \alpha \rho \sigma i ́ \alpha]$ ' (6:19), which sounds quite similar to God's 'handing them over' to be ruled/enslaved by 'impurity ['ak $\alpha \theta \alpha \rho \sigma i \alpha]$ '. Similarly, in 6:21, Paul speaks of former deeds on account of which they 'are now ashamed' (cf. ớtıนá $\zeta \varepsilon \sigma \theta \alpha 1$ in 1:21; cf. 'the passions ótıนías' in 1:26). What of the similarities between Romans 1:18-32 and 1 Thessalonians 4:3-8? Did the author of Ephesians 4:17 (with its very similar description of non-Christian humanity) also wrongly presume that Romans 1:18-32 was Paul's? And what of the vice lists found elsewhere in Paul? Finally, why would Paul include a doxology (v. 25) in the Teacher's 'tirade'?

\subsection{Romans 2:1-8}

In 2:1 Paul responds by subverting the Teacher's accusations by universalising them (547): the Teacher basically says Gentiles are 'stupid' (544), and Paul responds by saying the Teacher is 'stupid' (549) as well. Paul's rhetorical move here, if not benevolent, is undoubtedly effective (if retributive): the Teacher is getting what he deserves. But Paul's strategy raises a question: in 2:1 have the 'repugnant tone' and 'absence of self-knowledge' that squarely mark the Teacher in 1:18-32 really been left behind?

But Romans 2:1 contains a far more serious, arguably crippling, challenge to Campbell's entire reading. Regarding his reading of 2:1 he contends that 'one of its most important advantages ... [is that] we do not need to insinuate legalistic Jews, or judgmental, moralizing Christians, or Paul himself, into the ongoing argument (thereby unleashing a raft of ultimately debilitating theoretical consequences). 
The arrogant and pretentious Teacher has now been identified and addressed explicitly.' (548, my italics). That is, from 2:1 onward Paul addresses a very definite historical figure. But how does Campbell

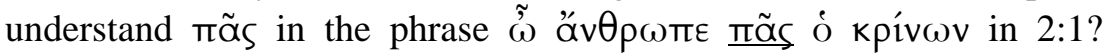
Incredibly, he does not address this in his exegesis (547). Later, in his suggested translation of 1:16-3:20 (587), he translates 2:1: ‘2:1 Therefore, you have no excuse ... ${ }^{139}$ when you judge others...'. (The first ellipsis is his; the second, mine.) Note 139 reads, 'Excising "whoever you are".' A similar excision is made at 2:3. The latter excision (in 2:3) is arguably less significant, but the former has massive consequences. What Campbell perceives as one of his reading's 'most important advantages' is gained at the (unexplained) excision of the very little—but very important-word $\pi \tilde{\alpha} \varsigma$. Whether $\pi \tilde{\alpha} \varsigma$ is translated comprehensively (e.g. 'everyone of you who passes judgment' [NAS]) or indefinitely ('whoever you are' [NRSV]), does this adjective even remotely suggest that a definite, historical figure has in fact 'been identified and addressed explicitly'? (Also, note the additions that have been made in his translation.)

\subsection{Romans 2:9-29}

If 2:1-8 subversively universalises the opening premises of 1:18-32, here Paul is 'using the definition he has just extracted [in 2:1-8] from the Teacher's rhetorical opening [1:18-32]—the principle of desert-to override the Teacher's own suite of supposed Jewish advantages' (551). In verses 9-16 the Teacher's 'principle of desert is applied [subversively by Paul] to Jews and then to sinful Jews, with the further clarification that judgment will not now be in terms of mere appearance. Moreover, pagans must [according to the Teacher's logic] possess some sort of internal law naturally' (552). This is plausible (if a bit confusing), but Campbell knows that his reading greatly struggles to account for the repeated statement 'first for the Jew and then for the Gentile' (vv. 9-10). Do these phrases not actually call attention to and affirm a Jewish 'ethnic or historical distinctiveness' which the Teacher's 'principle of soteriological desert', according to Campbell, utterly negates? Why would Paul twice highlight this? Campbell dismisses the word 'first' ( $\pi \rho \tilde{\omega} \tau o v)$ as 'essentially meaningless' and maintains that the phrase as a whole is 'fundamentally ironic ... probably "parodic"' (552), for Paul is actually 'quoting the discourse of the Teacher', who 'almost certainly argued for Jewish priority in 
salvation' (553). At first this appears ingenious but is in fact quite problematic: by construing this phrase as part of the Teacher's discourse, Campbell is forced to do the same with the phrase's occurrence in 1:16, before the Teacher first enters in 1:18. Why would Paul insert into a statement of his own gospel a phrase from the Teacher's discourse? Campbell answers: to underscore that the notion of Jewish advantage is 'overridden by God's salvation of "everyone who trusts"' (553). But is this not asking a bit much of the auditors (and the text's 'performer'), who have not yet even been introduced to the Teacher? Simply asserting that the repeated phrase in 2:9-10 has 'no effective or essential usefulness within the argument' (552) does not help. Campbell must explain how this phrase 'fits' into Paul's argument.

As mentioned, 2:6 and 2:16b contrast the two gospels: in the first gospel, the final judgement is by works; in Paul's gospel, the final judgement is 'through Christ Jesus', such that 'the role of Christ in the judgment...will presumably substantially shift the tenor and criteria of that event' (558, my italics). But such a statement both (1) at this point in the letter and (more critically) (2) within Paul's thought in general (much less the NT as a whole) is unsubstantiated (cf. Matt. 16:27, a Christologised statement of Romans 2:6 [Ps 62:13; Prov. 24:12]). He anticipates this response and contends that, with the possible exception of Romans 14:4b-12, (1) elsewhere in Paul Christ is always involved in the judgement (unlike the Teacher's 'day') and (2) nowhere in Paul is the future judgement viewed as a time when the Christian's salvation is at stake-i.e. as it is in the Teacher's thought (n. 93, p. 559/1085). But several questions arise. (1) Does Christ's involvement in the judgement establish that it will necessarily 'shift the tenor and criteria of that event'? Could not God conceivably fulfil 2:6 through Christ? (2) In view of 2 Thessalonians 1:7, does not such a view drive a massive wedge between the undisputed Paul and his disputed letters (along with the gospels and Revelation), suggesting either that (1) their authors substantially departed from Paul's own eschatology/Christology, being more sympathetic to the Teacher; or that (2) like the rest of the Christian tradition, they misread Paul—not merely Romans 1-4 but his entire, sustained campaign against the movement of this Teacher.

Romans 2:17-29 further indicts the same Teacher targeted in 2:1 (559). Verses 19-20 resume the Teacher's self-righteous judgements of 1:18-32 in that the description of Gentiles is the Teacher's 
(false/judgmental) perspective: he unfairly refers to such persons as 'blind', 'in darkness', 'foolish', mere 'children'-i.e. as 'ontologically inferior' (562, his italics). The real Paul, Campbell avers, would never speak of (unbelieving) Gentiles in this way. But does he not? Already Paul has spoken of an obligation to the óvóptor $(1: 14 ; 2: 20=$ áppoves). And what of the discourse on folly/wisdom in 1 Corinthians 1-3? In 2 Corinthians 6 he contrasts believers with non-believers: 'what fellowship can light have with darkness?' (cf. 1 Thess. 5:4). Colossians describes the recipients' conversion in terms of deliverance from darkness (1:12-13; cf. Eph. 5:8; cf. 5:14). Acts defines Paul's entire apostolic mission in these terms of both darkness/light and recovery of sight (26:17-18; cf. Isa. 49:6 in 13:47). Also, Paul readily uses parental (indeed, patriarchal) metaphors (e.g. 1 Cor. 3:1; 4:15; 14:20). In short, Paul (and the Pauline tradition) describes unbelievers much like Campbell's Teacher describes Gentiles. In truth, the critique in 2:17 is not that Paul's Jewish opponents taught others (instead of being good pluralists); it is, rather, that they did not teach themselves. These similarities are significant, for they suggest that, on Campbell's reading, the differences between the Teacher's diagnosis and Paul's simply are not that great, while the difference between their solutions is (Torah vs Christ). If so, this calls into question Campbell's entire programme at what he considers to be a crucial point (cf. 518-29).

\subsection{Romans 3:1-9}

In chapter 3 (cf. 571-72), though 'the Teacher's missionary program to the pagans is [now] in ruin ... he [along with his converts] ... is not yet utterly forsaken' (571); that is, his gospel could still save himself. But his hope, the Torah, will actually be his undoing, as the catena of 3:1020 will reveal. But first Paul in 3:1-9 lures the Teacher into unknowingly affirming the apostle's argument; for if the Teacher is to be consistent, 'God will judge all for their sinfulness on the basis of desert, and irrespective of any special privileging or pleading' (572). Campbell places 3:1, 3, 5, 7-8a, 9a in Paul's mouth, with the remainder in that of the Teacher, the 'representative of the principle of desert' (573). But if so, where did the terminology of 'the principle of desert' go, and why the introduction of $\pi 1 \sigma \tau-$ and $\alpha \lambda \eta \theta$ - terminology? That is, when the discourse of retributive justice (cf. 2:6) is most in order (for Paul is here 'cornering the Teacher ... and in terms of the Teacher's own assumptions' [574]), the ' $\rho \gamma^{-}, \pi \rho \alpha \sigma \sigma-, \pi 01 \varepsilon-$, vop- terminology 
drops from view and is replaced by the more ambiguous, slipperyeven participatory?-discourse of ríotıs. In short, if Paul is wanting (1) to use the Teacher's own words against him and (2) to make sure that his Roman audience makes the connection with what precedes, the introduction of new terminology by both Paul and the Teacher in 3:1-8 is simply not the best way to go and therefore all the more demands an explanation. Campbell senses this and provides dubious hypotheses: Paul is 'reorienting the dialogue toward God' (575); the terminology 'indicates that the Teacher's fundamental conception of God is potentially limited' (578).

Other obstacles to his reading of 3:1-8 include: Can he make sense of the 'aside' in verse 5 ? Is his division between speakers at the end of verse 8 really that plausible? (I.e. does it make sense that a new speaker begins with a relative pronoun?) Also, how plausible is it to translate

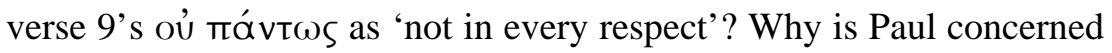
about divine glory (vv. 5, 7-8)? Perhaps most problematic of all, his construction of (what he considers) Paul's climactic rhetorical move in 3:9 rests upon the following construal of mpoaıtı́a 9 (579): the про- prefix must be understood not temporally ('before now') but spatially ('before persons'-i.e. publicly); the 'we' is an apostolic 'we', and the aorist is 'epistolary', so that it refers 'simply to Paul's public charge through the Scriptures prior to the actual receipt of the letter by the Romans' (580). Is this not a counsel of despair, if not desperation? To designate it as an epistolary aorist ignores the rhetorical situation (on his own reading) and consists of an action unlike any other epistolary aorist in the NT (oddly, in his paraphrase on p. 581 it is in the present tense; cf. the addition in his translation on p. 590).

\subsection{Romans 3:10-18}

Here Paul delivers his final blow to the Teacher's argument: 'an external authority-which the Teacher nevertheless clearly acknowledges - is introduced to refute it definitively' (583). This authority is crushing precisely because the texts are to be interpreted, we are told, within the strictly retributive and self-saving soteriological framework of the Teacher (how this fits with Paul having publicly read them aloud before sending the letter is not discussed). Therefore, 3:1920 is a statement of the devastatingly inescapable logical conclusions of the Teacher's own argument: everyone, including the Teacher, is 
silenced and held accountable, so that through the Teacher's gospel (= 'works of the law') no one will be justified. This is plausible, but does the text lend itself to such particularity? Torah speaks 'to those who are under the law', not to a particular Jewish-Christian Teacher; does the repeated use of mã s point to a definite, historical figure? Is 'works of the law' really a summary of the Teacher's gospel (585; cf. 859). Finally, and as we shall see momentarily, he understands $\delta$ ikaı́ $\omega$ here as 'to justify', but in a few verses the word means something entirely different.

Before moving to Campbell's exegesis of 3:21-26 (and 1:16-17), we step back and consider 1:18-3:20. According to Campbell, in this section 'Paul's unfolding strategies ... are designed to exploit the tension in the Teacher's theology between contentions based on fairness and contentions based on ontology - that pagans and Jews are ontologically and ethically different' (571). But from our critique thus far, it is clear that Campbell struggles when he actually attempts to locate this ontological difference in the Teacher's thought. This is most evident in Campbell's attempt to find the Teacher's solution in the supposed ontological surgery of circumcision. Ironically, elsewhere Campbell warns the modern reader against precisely this dichotomy (678-81): one must not read into Paul a dichotomy between 'the forensic and ethical dimensions ... Much debate in this relation seems to assume a strong distinction between being and act ... a staple assumption of much Western thought' $(679,680)$. Campbell, then, urges the modern reader not to find such a dichotomy in Paul's own thought but only in the Teacher, who was very modern/Western in his thinking.

\subsection{Romans 3:21-26; 1:16-17}

Romans 3:21-22 begins 'the second major argumentative phase in [Paul's] critical engagement with the Teacher's gospel in Romans 1-4', in which Paul employs the Pentateuch to claim that Abraham received righteousness (= deliverance) from God prior to, and hence, apart from Torah observance and/or circumcision (625). As for 3:21-26 (and 1:1617) Campbell's basic strategy turns on a Christological interpretation of ríotıs (as representing the entirety of Christ's life, death, and resurrection). Furthermore, because little in Romans 1:18-3:31 actually reflects Paul's perspective, these statements should be understood within the context of (the unadulterated Pauline) chapters 5-8, such 
that 1:16-17 and 3:21-26 anticipate these later chapters. Hence, their interpretation is to be framed by 'apocalyptic' and participatory constraints (cf. summary on 711).

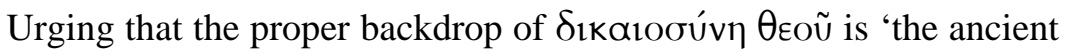
discourse of kingship' (690-91; cf. 683 for his method), Campbell leans on various OT passages (e.g. Ps. 98, 143) to conclude that the phrase speaks of a 'liberating or delivering act' of God, consistent with Käsemann (694; cf. 688, 699 for the phrase in 1:17). In short, through Christ's faithfulness, 'God is operating as the divine King ought to, delivering his captive creation from its bondage; he is therefore doing the 'right' thing, acting as his character and role demand' (702). Through Christ's faithfulness God is disclosing his delivering nature/action. Campbell maps 3:21-22 onto 1:17, interpreting 'through the faithfulness of Jesus Christ' (3:22) and 'from/through faithfulness' (1:17 twice) instrumentally, making both of the latter phrases (and, hence, the Habakkuk citation) Christological and instrumental. Romans 3:23-26 elaborates 3:21-22 (607): verse 23 speaks of an 'enslaved' humanity while verse 24 speaks of God's justifying (= delivering)

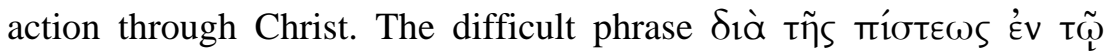

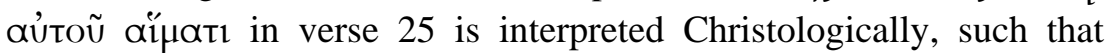
'Christ's "blood” glosses (Christ's) "faithfulness", which both in turn inform the meaning of the previous clause, which Campbell paraphrases: 'God intended Christ to be a i $\lambda \alpha$ arńpiov'; the language, then, points to Christ's martyrological 'story of faithfulness [which] culminated in that virtue's supreme test-death' (642).

Viewing the plural 'sins' (v. 25) as betraying traditional material, he maintains that Paul's portrayal of the atonement in 3:23-26 is 'meant to echo the auditors' traditional position in Rome' (708). But Paul's view of Christ's death is 'far more radical' than the tradition, for in Paul 'atonement is effected for Christians ... as they participate in Christ's death and resurrection; this effects a much deeper liberation from the very power of Sin, not merely cleansing from sins' (709). Is this, then, what 3:23 says? No, admits Campbell, but Paul first states a quasitraditional view to gain the necessary rapport so that 3:23-26 'creates rhetorical pressures in this direction that prepare the way for his later, more explicit claims' (709). But what are 'rhetorical pressures' and how does one spot them? And how can Campbell justify his distancing of Paul from the tradition (vis-à-vis Christ's death) in light of 1 Corinthians 15:3? 
Verses 25b-26 communicate that all of this was a demonstration of God's delivering nature/action (i.e. 'righteousness')—i.e. so that God might be 'righteous'/delivering and the one who delivers Jesus because of his faithfulness (v. 26; cf. 672 for this interpretation). Campbell concludes by stating that the rhetorical aim of 1:16-17; 3:21-26 is (1) to juxtapose 'two irreconcilable conceptions of God and the Christ event' and (2) to 'reframe' the Roman auditors' conception of the atonement (704). The first concerns 'presuppositions' (707), while the second is a 'subtle strategy' (711).

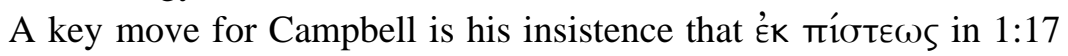
must be instrumental in a way that rules out the traditional rendering '(human) faith': how could God 'reveal' his righteousness through human faith (377)? Hence, ríotıs must be rendered 'faithfulness' and refers to Christ's faithfulness, which serves perfectly as an instrument of divine disclosure. Campbell is right to say that $\pi 1 \sigma \tau-$ and $\dot{u} \pi \alpha$ kovterms overlap semantically (612) but wrong to see $\pi 1 \sigma \tau-$ in terms of believing/belief as incompatible with ómока $\lambda$ úr $\tau \omega$. The passage to which he (rightly) appeals to establish the former negates the latter, namely Romans 10. Verse 16: 'But not all obeyed the gospel. For Isaiah says, "Lord, who has believed our message?”' Critically, in the very same line of the Isaiah citation, in clear parallel, is the following:

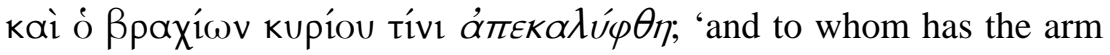
of the Lord been revealed?' Are not 'obeying', 'believing', and 'revealing' all functioning in concert, reflecting different aspects of a singular event, in which God reveals his arm by his messenger and recipients (are supposed to) obey/believe it? Moreover, Campbell's

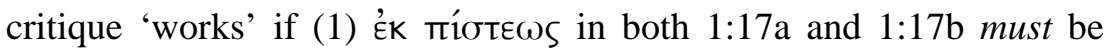
understood identically, and if (2) one should turn elsewhere in Paul to

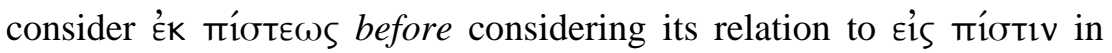
1:17a. His argument certainly makes these conditions possible but hardly necessary.

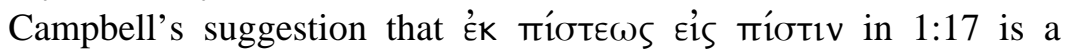

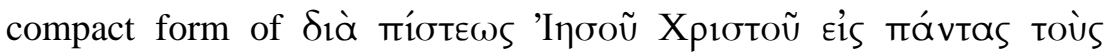

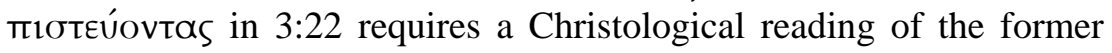
that the context does not invite: how would the auditors have known to

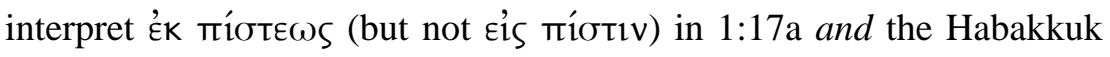
quote in 1:17b Christologically? The last time Christ was mentioned was verse 8 (and in a passive, mediatorial way). Again, it seems that Campbell's exegesis demands too much of the auditor. 
Although 3:24-26 is a difficult text, his discussion is extremely slippery and almost lethally piecemeal. For him Paul's use of cultic terms merely 'fulfills a flexible and ornamental function, gracing Paul's prose with occasional Levitical flourishes' (651; cf. 708). Then his Christological reading of míotıs in 3:25 places 'a martyrological narrative at the center of the text's atonement terminology and its significance' (647; cf. 653). He then introduces Genesis 22 and 4 Maccabees into Romans 3:25, so that 'the story [in 3:25] now speaks fundamentally of God's benevolence (and not his caprice, as seems apparent when he stands outside the story) as the beloved son is offered up to save a hostile humanity' (654).

Critically, Campbell's reading demands that Paul uses Sıkaı́w in two very different ways: there is Paul's meaning ('to deliver') and the Teacher's meaning ('to declare righteous') (668). Could the auditors have discerned this difference, e.g. construing the verb as 'to justify' in verse 20 but 'to deliver' in verse 24? Campbell himself finds it difficult to tell them apart in 3:28 (719), and he admits that the meaning of the verb's two occurrences in 3:23-26 is 'ambiguous' (709), so that in verses 24, 'by emphasizing its [the verb's] forensic-liberative possibilities ... [Paul] is able to draw this signifier ... into his own system' (668). But Campbell's argument backfires: the modifiers in verse 24 ('freely, by his grace', etc.) that (supposedly) 'emphasize [the verb's] forensic-liberative possibilities' actually reveal that $\delta$ เkaı́ $\omega$ does not in itself have the connotation of 'benevolence' that he claims; rather, in the sentence these modifiers, not the verb, contribute the notion of 'benevolence'. Therefore, when $\delta$ 1кaı́ $\omega$ appears without such modifiers (i.e. in 3:26, 28, 30; 4:2, 5; 5:1, 9; 8:30, 33), can the notion of 'benevolence' still be present? Hardly. But the verb must have a benevolent connotation in most (if not all) of these subsequent occurrences, if Campbell's reading is to work.

Furthermore, it is simply not the case that $4: 5$ (tòv $\delta$ 1kaıũvta tòv ' $\sigma \varepsilon \beta \tilde{\eta})$ 'specifically rejects the forensic-retributive interpretation of God and hence that interpretation of the verb $\delta$ ikalów as well' (668, his italics). The verb's patient ('the ungodly') in no way indicates that the verb means 'to deliver' instead of 'to declare righteous' (no more than the word 'murderer' alters the meaning of 'acquitted' in the sentence 'The judge acquitted the murderer'; the sentence may surprise us but only and precisely because the meaning of 'to acquit' does not change). Campbell's work here is pre-Barr lexical-semantic 
scholarship, and it is difficult to escape the conclusion that it compromises his entire reading of Romans 1-4.

In addition, Campbell uses 3:25 to arrive at a particular conception of atonement and then from this 'backs into' the meaning of Sikaı́ $\omega$ in verse 24 . While this is perhaps fair methodologically, Paul's auditors would have had no such luxury but would instead have had only the former $\delta_{1 k \alpha 1-}$ terminology at their disposal-i.e. 2:13; 3:4; and especially 3:20. This last occurrence is especially difficult in that Campbell has Paul attempting to achieve two nearly antithetical goals with the opening phrase of 3:20. First, it serves as the inescapable and incoherent logical outcome of the Teacher's own logic and, therefore, the verb $\delta$ ikaı́ $\omega$ means (true to the Teacher's discourse) 'to declare righteous'. But, second, the clause prepares the way for 3:21, for, according to Campbell, 3:20a echoes Psalm 142:2 LXX, the context of which 'specifically repudiates retributive activity by God' (698, his italics; this is a surprising claim, especially in view of vv. 1, 12).

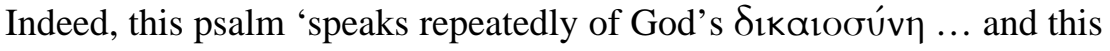
contextual material can hardly be coincidental when Paul is about to resume that motif emphatically in Romans 3:21, 22, 25, and 26. It seems, then, that the rest of the psalm is implicit within Paul's allusion' (698). Therefore, Campbell has Paul quoting a psalm that (1) repudiates divine retributive justice, (2) speaks of God's 'righteousness', and yet (3) is employed to summarise the Teacher's incoherent argument and (4) uses $\delta$ ikaı́ $\omega$ in a way consistent with the Teacher. The Roman auditor, then, should take from this allusion a rejection of retributive justice, a signal of a rhetorical turn to a radically different understanding of God's righteousness (in 3:21), but the auditor should leave behind the meaning of $\delta 1$ kıı́ $\omega$. How realistic is this?

In sum, if two very different conceptions of God lie behind Paul's gospel and the Teacher's, it would seem extremely dangerous to use $\delta 1$ k $\_$ió $\omega$ to denote two radically different conceptions of God (and of divine action), especially when Paul's rhetorical strategy thus far (i.e. up until 3:21 [663]), has been overwhelmingly deconstructive. I am not objecting to the idea that $\delta$ ikaıó could (and probably does) have two different meanings in Romans (due to 6:7), but the indicators for such a differentiation must be more explicit-e.g. a change in the verb's syntagmatic relations, as is evident in 6:7 (but this distinguishes 6:7 from 3:24 [etc.], not 3:24 from 2:13, much less 3:20, as Campbell 
needs). Indeed, Campbell would have to defend why his definition of $\delta ı$ «ıó $\omega$ as 'to deliver' still holds in 6:7. But does the addition of ámó betray no semantic shift whatsoever? Ironically, Romans 6:7, then, is probably quite problematic for Campbell's reading.

It is interesting that Campbell construes 'the righteousness of God' via 'the ancient discourse of kingship' in the OT (e.g. 1:17 echoes Ps. 97 LXX; cf. 689), as this discourse is shot through with covenantal/contractual agreements, retributive justice, and endorsements of violence (he hints at but minimises the dangers in n. 71, p.

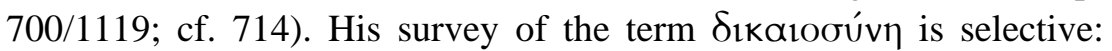
some OT texts—e.g. various psalms - are inexplicably more germane than others. For example, he cites the occurrence of Sikaıooúv $\eta$ in Psalm 7:18 LXX but neglects aspects of that psalm that specifically call for retributive justice (ironically, 7:9). To say that ' $\delta$ ikaıooúv $\eta$ not infrequently denotes a liberating or delivering act' (694) invites an obvious question: what does it frequently denote? Even if one were to grant that 'it is not uncommon to find God acting in the OT to liberate those who have been held captive irrespective of whether or not they actually deserve liberation' (661, his italics), the OT, Psalms of Solomon, and other Jewish literature attest to both retributive and deliberative aspects of divine (and human) justice alongside each other, forcing Campbell to create a second-order hypothesis that PssSol 'debates and disagrees over the divine character' (667), as do 4 Ezra and the Qumran literature (665) and, it follows, much of the OT. So he then hypothesises that in Paul's day 'the character of God was diverse, if not debated' (667). To that debate 'Paul ... brings a critical qualification ... His view of God has been decisively qualified by the Christ event, to the point that any previous views seem to have beenif necessary-fundamentally renegotiated' (n. 83, p. 707/1120). But if so, why and how does Paul state that 'the righteousness of God' is attested by 'the Law and the Prophets'? Is this a conflicted testimony?

A final challenge to his reading of 3:21-26 concerns his contention that Paul's rhetorical strategy is to maintain that 'cleansing and hence freedom from sins' leads to and, hence, is the 'freedom of resurrection' (710), such that the conception of the atonement in 3:21-26 prepares the auditor for the atonement in chapters 5-8. Is this what Romans 3:21-26 says? Well, Campbell admits, only ‘subliminally’ (710). But Christ is a i $\lambda \alpha \sigma \tau$ ńprov—how? - by Christ's faithfulness, by means of his blood' (so Campbell translates). Even if we grant that Christ's 
resurrection is implicit in his 'faithfulness', the particular aspect of that faithfulness highlighted by Paul here is his death ('blood'), not his resurrection. If Paul is wanting to move the Romans from what Campbell believes is the 'early church's' view of the atonement to his own (i.e. via Christ's resurrection), Paul has emphasised the wrong thing (leaving aside the ethical matter of an argument that alters the earliest church's conception of the atonement in a way that looks like no change has been made; cf. 713). Campbell admits that it is 'slightly puzzling' that there is an 'absence of resurrection thematology and terminology in 3:21-26’ (665).

\subsection{Romans 3:27-31}

Here Campbell sees another dialogue between Paul and the Teacher, who makes a number of objections, asking in turn 'about one who ... boasts in his works, about what has happened to a teaching of "works of the law", about the Jewish preferences of what is, after all, the Jewish God ... and about the possibility that Paul's key principle, ríotıs, will eviscerate the Pentateuch' (717). While Paul gives a brief initial response to these objections, he provides a fuller response to each in turn in 4:2b-16 (cf. 725). Campbell's construction of the dialogue (cf. 716) struggles at verse 30; it is an understatement that (in his construal) 'Paul's rejoinder to the Teacher's query is not quite to the point' (720). Indeed, his construction is not easy to follow and, e.g. Paul's initial reply in 3:27 ('It is excluded') is, even to Campbell, 'cryptic' (717).

His contention that from 3:22 onward mírtıs refers to Christ's faithfulness is most problematic. For example, how does Campbell understand the term in 4:5? We do not know, because he never discusses it. This is inexcusable: how can Campbell confidently assert that ríotıs in 3:28 must refer to Christ's faithfulness (718-19), refer to the same in 3:31 (735) and yet speak about Abraham's 'trust' (in opposition to 'works') in 4:2-8 without ever discussing níotıs in verse 5 , especially when (1) he understands $4: 2-8$ to be an expansion of the issue brought up in 3:27-28 and (2) both 3:28 and 4:5 contrast 'works' and ríotss (cf. ríotıs in vv. 9, 11, 12, 13, 14, 16 [2×], 19, 20)? Not only has an explicitly Christological conception of ríotıs (apparently) disappeared in 4:5, but the term suddenly no longer means 'faithfulness' but 'trust' (cf. 723). We highlight the use of mírtıs in 4:5 because of its similarity to 3:28. But míotıs in 3:31 is also very 
difficult for Campbell: in what sense does míotıs, as the faithfulness of Christ, uphold the law? Campbell solves the problem by moving on to his exegesis of 4:1 (he strangely states, 'Paul has exploited an ambiguity at this point once again' [722]).

Campbell understands 3:28 as 'one of the most compact statements of [Paul's] countervailing system that he ever supplies; indeed, it is so compact that interpretive reductionism has arguably resulted' (718), for

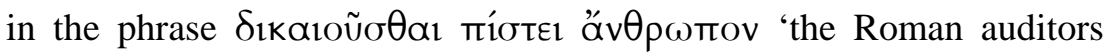
should recognize ... a conflation of the two narratives that Paul has previously placed in a progression-the progress of God's eschatological salvation through the faithful Christ and his resurrection to those who trust and will therefore be resurrected, allowing in turn the statement that God "delivers a person by means of [both Christ's and the person's] fidelity." Why does Paul conflate? It is done 'in the interests of brevity and repartee' (718). But could the auditors have discerned this conflation? Again Campbell has Paul doing too many things at once. Also, why ever does he translate kaúxๆors as 'the boaster' (718-19)?

\subsection{Romans 4:1-25}

Paul writes Romans 4 because the Teacher might appeal to Abraham when he arrives in Rome, for 'Paul, of course, would not be advantaged by any such appeal' (722). In short, the Teacher forces Paul to discuss Abraham. (This illustrates well how significantly Campbell's construction of the letter's occasion informs his exegesis.) The Teacher's questions from 3:27-31 are more fully answered (in turn) in 4:2b-16a, a section which contains a weakness (i.e. its implicit references to a post-circumcision Abraham) that is then haphazardly ameliorated in 4:16b.

According to Campbell, Paul ingeniously exploits the figure of Abraham by referencing the patriarch's pre-circumcision faith. But, as just noted, such a view does not account for Paul's use of postcircumcision Abrahamic material (much less David), such that Campbell's reading introduces an 'acute problem' for Paul (738). But is Paul's reference to Genesis 17:5 problematic? Is his argument contra-circumcision per se or is it is contra-circumcision (and Torah) as definitive for the identity of the true Jew?

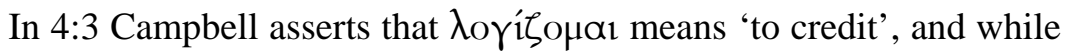
'no doubt' commercial in its ancient context, yet it 'holds the 
possibility of a nonmeritocratic deployment' (730-31). But is there no relationship between Abraham's believing and God's crediting? His analogy of a 'penurious son or daughter' being credited with parental funds falters, for such a son or daughter does nothing, but Abraham does: he trusts, and plainly this trust prompts divine action. His

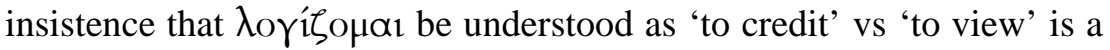
false dichotomy: to credit a status of righteousness is the same as to reckon one righteous. The quotation of Psalm 32 makes this plain: does God actually 'credit/give' sin to someone? (Note 34, p. 730/1123, reveals that he is aware of this, but it is not evident in his argument, which assumes a mutual exclusion. And it must, if his definition of

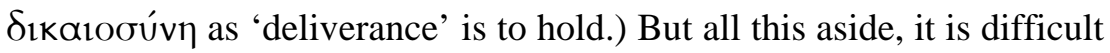

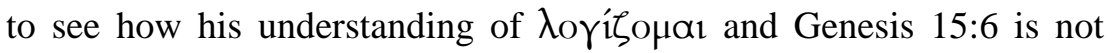
essentially contractual: according to Campbell, God is 'paying' something to Abraham in response to the patriarch's faith (731).

Verse 13 is also difficult for Campbell. He provides no explanation for the substance of the promise: what does 'heir of the world' mean? For Campbell, God made a very personal promise to Abraham that he would have a son (cf. 749). But if so, who are the 'heirs' of verse 14? Campbell also struggles to understand Paul's statement, 'law works wrath' (4:15). Is this hypothetical or perhaps a 'parenthesis' (734)?

His contention that 'seed' both in Romans 4 and in its original context refers only to Isaac (738) is problematic. First, whoever wrote Genesis wrote it not for Abraham but, precisely, for his seed-i.e. his descendants; therefore, to suggest that a 'plural application of this promised inheritance' can be made only 'eventually' is dubious. Second, Romans 4 simply does not support Campbell's suggestion that Paul makes the initial, singular application of Genesis 15:5 in verses 13 and 18, and then an 'eventual' plural application in verse 16a ( $\pi$ avti

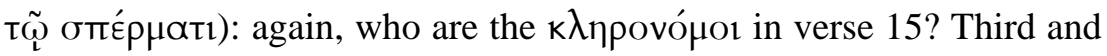

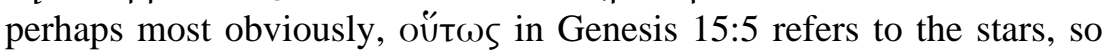
that equating 'seed' with Isaac yields the dubious translation 'Like the stars in the heavens thus shall your son Isaac be'.

In addition, for Campbell Paul's argument in 4:16b-22 fails logically: the Teacher actually possesses a legitimate counter-argument that could expose Paul's appeal to Genesis 17:5 (which is no longer pre-circumcision), and so Paul hastily returns to Genesis 15:6 (739-40; cf. Paul's strategy on 741). This makes Paul's argument logically invalid and/or deliberately deceptive. Paul's argument is 'a mixture of 
bombast, pathos, and narrative suggestion' (744); Paul's argument does not actually work but 'we tend not to notice this omission; our attention is otherwise engaged!' (744, his italics). In short, for Campbell Romans 4 is a logically unsuccessful polemic, forced by the probable employment of a logically coherent critique of Paul's argument by the Teacher.

Campbell's unargued rendering 'from hope to hope' in 4:18 is probably impossible (the phrase would probably be É ... E's, not тара́ ... Éтrí). But does the first rendering account for verse 19, in which Abraham 'trusts in spite of "the death" of his loins and the “death” of Sarah's womb' (742)? Then, confusingly, on page 389 he translates the phrase 'from hope to hope', but on page 393 translates 'against hope in hope'; hence, the latter is apparently quite plausible (unless Campbell has contradicted himself).

In his discussion of 4:23-25, one finds the following. Here 'God is ... implicitly characterized as a "father”, like Abraham' (746). Verse 25 'evokes' a 'martyrological narrative neatly' with a 'trajectory of descent' and a 'trajectory of ascent', and the verse also 'elaborates precisely on the two facets of Habakkuk 2:4 ... that have spoken earlier

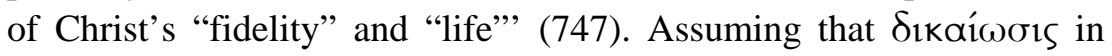
verse 25 is identical to $\delta$ koııoúv $\eta$, he states, 'There is no avoiding the correlation between "resurrection” and $\delta$ ikaíwoıs' (747). Furthermore, Paul here speaks of 'the deliverance of humanity from a realm characterized by transgressions and death' (747). Campbell finds here 'an emphasis on Christ's death and life as a saving narrative (in which God "the Father" is also deeply involved)' (747). By verse 22 'the Teacher's argument lies in ruins' (a strange conclusion, as Campbell maintains that Paul's riposte against a devastating critique from the Teacher in vv. 16-22 does not logically work). In verse 25 Christ's work results in 'cleansing from transgressions and liberation from the entire realm of Death' (748); he concludes, 'Paul's position is fundamentally apocalyptic' (750). These are all provocative statements, for which the reader awaits Campbell's rationale and is sorely disappointed to discover that he never even attempts to offer one.

On Campbell's reading, how can Paul say that 'the words "it was credited to him” were written ... for our sakes'? Does it really make sense that Isaac's miraculous birth constituted in toto God's

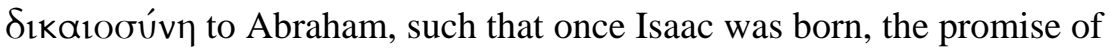


Genesis 15:5 was a fait accompli (749)? And when, if ever, was the promise of Genesis 15:5 fulfilled for Abraham?

Finally, Campbell never explains how verse 25 works: why was Jesus handed over for the sake of the cleansing of our transgressions ... and why was he raised for our deliverance? How do these work, and how do they fit into the argument of the chapter?

\subsection{Romans 5-8}

Campbell's overview of Romans 5-8 (62-73) contends that 'God's fundamental posture toward humanity $\ldots$ is unconditionally benevolent' (71). His reading, however, does not account for the reality of future divine wrath (in 5:9; cf. 1 Thess. 5:9-10) nor does he suggest in what way those not 'justified/delivered by his blood' can justly be held accountable (cf. 66). Furthermore, in 5:6-11 the concepts of a future divine wrath, sinners as 'enemies', Christ's 'blood'/'death', and 'reconciliation' are all mutually interpretative and so problematic for his reading. For example, can his description of Christ's death exclusively as 'cleansing' and/or as 'a critical [ontological] transitional moment for humanity' (88) account for why God will exercise wrath and why sinners are 'enemies'? Furthermore, in light of (1) the imperatives in chapters 5-8 (e.g. 6:12), (2) the way in which various soteriological realities make the Christian into 'debtors' (8:12) and (3) the explicit conditions of texts like 8:13 and 8:17 (cf. 11:20-21), can it be said that this 'alternative soteriology' of Romans 5-8 is 'unconditional'? Campbell himself speaks of actions that are 'necessary' for salvation $(66,68)$. But if so, would it not follow (on his own rationale) that 'conditionalism and contractualism are thereby unleashed at every point' (438)? Also, if this atonement actually delivers all men, why is it 'wise not to second guess the eschaton and pronounce definitively $\ldots$ on the future salvation of the human race' (78)? What greater warrant do we need than Romans 5:18 (on his reading)? Furthermore, Christ's death constitutes an " "atonement” in the broadest sense of the term' (76). But what is the broadest sense of the term? Finally, we note that his reading of 5:1-2 can be paraphrased, 'Being delivered through the faithful one Jesus Christ, we have peace with God through our Lord Jesus Christ, through whom we also have access by means of the faithfulness of Jesus Christ into this grace' (823). Is this plausible? 


\subsection{Romans 9-11}

How does Campbell understand Romans 9-11? 'In essence, the Teacher seems to have asked whether the anomalous salvation history generated in part by Paul himself calls Paul's version of the gospel into question' (771). Elsewhere, however, Campbell has maintained that the Teacher's own soteriology is ahistorical (but see n. 18, p. 772/1130). Indeed, the Teacher's gospel (which, Campbell avers, shares most/all the fundamental presuppositions of his modernistic Justification theory [cf. 760]) is 'timeless, ahistorical, individualistic, and contractual' (780). Furthermore, the Teacher's challenge to Paul is, as Campbell admits, just as much the Teacher's own, for he too is a Christian. Why, then, would the Teacher bring it up? Merely because Paul is making the problem worse by allowing some pagans to enter in a law-free manner? The Jewish rejection of Jesus as the Messiah, which Campbell views as widespread in Paul's day, can hardly be laid at the feet of Paul's law-free gospel. So does such a challenge from the Teacher really make sense? Finally, Campbell admits that in 9:27-10:10 'the apocalyptic re-reading of Paul faces perhaps its most difficult challenges' (cf. 782), and it is not hard to see why.

\subsection{Outside Romans}

As for Galatians, once it is conceded that Romans is addressing the same opponents as Galatians, it is not surprising that his reading of Romans maps onto Galatians (n. 6, p. 836/1141; cf. 844 for his summary of Gal. 2:15-16). We make just one observation. Given Campbell's argument that (1) Paul's gospel is fundamentally opposed to the Teacher's (which, Campbell maintains, is almost identical to Jtheory) and that (2) this opposition reflects a widespread debate within Judaism regarding the very character of God, why did Paul not write in a way that underscored the incompatibility of these soteriologies but rather wrote Galatians 2:15-3:5 (and 3:6-14; cf. pp. 856, 865) in a way that is 'fundamentally ambiguous ... [J-theory] might be present here in Paul, but it might not' (838; cf. his description of Gal. 3:6-14 as 'cryptic remarks' [859])?

His reading of Philippians 3 faces several obstacles, the greatest of which is that it requires two very different definitions of $\delta 1$ kalooúv $\eta$ in verse 9: the first is simply 'righteous activity', while the second is a description of 'the life-giving activity of God made available in Christ, 
and so, in other words, of the resurrection and subsequent life in glory' (906). But are these not two very different definitions of $\delta$ ikaıooúv $\eta$, despite his insistence that they have only 'subtly divergent connotations' 908)? But such a semantic manoeuvre might be permissible, except that the shift in meaning must take place too early in the participial clause: Paul desires to be found in Christ, $\mu \eta{ }^{\prime \prime}{ }^{\prime} \chi \omega v$

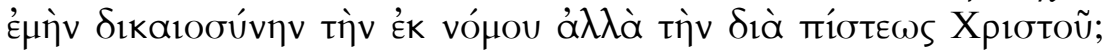
the two occurrences of the accusative article $\tau$ rn modify the initial

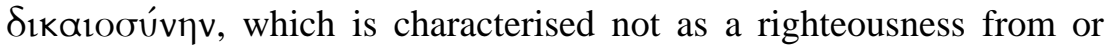
belonging to God but as Paul's. Stated positively, Campbell's rendering must be paraphrased, 'not having my pious activity which is from law but a divine delivering act through the faithfulness of Christ, the delivering act from God on the basis of Christ's faithfulness' (or, alternatively, 'not having my pious activity which is from law but a pious activity which is through the faithfulness of Christ, the delivering act from God on the basis of Christ's faithfulness'). This rendering might, as Campbell states, be 'fair to suggest', but is it remotely probable? That Campbell seems to recognise the problem is evident from his unfalsifiable comment that 'It remains only to note ... that Paul is probably punning here on the meaning of $\delta$ kaııoúv $\eta$ in v. 9', which is then followed by an admission that 'righteous activity' is a better definition for $\delta$ ıкaıơúv $\eta$ in verse 6 as well (907). But it seems Paul must be punning if his reading is to be a meaningful sentence, much less viable exegesis. As Campbell himself admits (908), for Jtheory advocates $\delta$ ikaıoúv $\eta$ in verse 9 is easily understandable. But when he states that 'there is no way of deciding in immediate terms whether this [J-theory's] reading or [his own] apocalyptic one is correct', a solution is in fact ready at hand: the one that does not have to argue that Paul is punning. In light of this, Campbell's charge that Jtheory proponents are 'advocates of interpretative ambiguity' (908) seems unfair.

Campbell argues that Philippians 3 'betrays no negative prior experience of Judaism; but quite the opposite; it is positive!' (902). But is not Paul's entire list of descriptors in 3:5-6 explicitly characterised by $\sigma \alpha ́ \rho \xi$ ? If so, would not $\sigma \alpha ́ \rho \xi$ have been 'negatively coded' by Paul both before and after his 'conversion'? Therefore, Campbell's conclusion that 'There is ... no need to characterize Judaism in and of itself and apart from Christ negatively’ (909) falters. 


\section{Exegesis: Concluding Comments}

We have occasionally noted that Campbell's reading appears to demand too much from Paul and far too much from his auditors. A comment from his exegesis of Romans 3:23-26 illustrates this well. In these verses Campbell finds 'a tight and repeated juxtaposition ... of notions stated in deliberately ambiguous and hence analogous terms [which] encourages their integration and not merely their sequencing ... None of this is explicated at length or more than hinted at in 3:2326. It is a subtle strategy' (711). A key word for Campbell is 'subtle'; Paul is almost ubiquitously subtle (e.g. 710, 711, 713, 745; 757, 912, 914). But at times 'subtle' probably means 'implicit' or perhaps even 'ambiguous', and it is not unfair to ask, 'What is Paul explicitly saying?' Given the subtlety, craftiness, asides, deviations, etc., of Campbell's re-reading, accurately 'performing' the text would have been a feat in itself. Campbell accuses J-theory advocates of making Paul difficult to teach (be it a minister teaching his congregation or a lecturer, his students) (n. 28, p. 186/977), but his reading of Paul's 'subtle', speech-in-character rhetoric will almost certainly not be easier.

Even as Campbell roots key Pauline concepts like 'the righteousness of God' in the OT, his apocalyptic reading posits radical discontinuity, even contradiction, with both the OT and Christianity's earliest origins. His reading 'exonerates' Paul of any critique of contemporary Judaism and offers a radically Christian (i.e. non-Jewish), intramural, and, therefore, inoffensive portrait of Abraham (759), a move which may appeal (at least to some) modern sensibilities, but at what historical cost? Earliest Christianity was a Jewish sect. How realistic (historically) is such radical discontinuity? 'The basis for this reading [i.e. for Paul's distinct reading of the Pentateuch and of the Jewish tradition] is Christianity, not Judaism, and the portrayal of Abraham that results is intended primarily for Christians (including Jewish Christians), not Jews' (759). But does this square at all with Romans 9:1; 10:1; 11:13? That is, why is Paul so concerned about his fellow Jews? What would Marcion think of Campbell's reading?

We have not considered Campbell's use of 'speech-in-character', focusing instead on his actual exegesis. But in view of the obstacles set forth above, it is worth questioning if he has avoided the pitfalls of mirror-reading (as set forth by, e.g., J. Barclay). The difference 
between what (Campbell claims) Paul does in Romans and what Paul does in 1 Corinthians (when referencing various Corinthian 'slogans' or statements) should be carefully considered. One must weigh cautiously the communicative challenges inherent when there are 'two senses in which the voice of the Teacher can be detected in this material' (587). That is, Campbell's reading posits not simply (or even predominantly) two opposing voices but rather one voice with a second voice 'redeploying' the first (with irony and parody) and 'using it' against it (587); the result is considerable complexity. His translation of 1:18-3:20 demonstrates this well (e.g. Rom. 2:17 on p. 589); the italicised words are the Teacher's, and yet at times they are actually Paul's, using the Teacher's words against him. Campbell provides no real criteria for discerning a change of voice, and even when the text contains an interrogative, Campbell concedes that it does not necessarily suggest a change of speakers (cf. 723).

Finally, how satisfying is his overarching strategy of reading Romans 1-4 in light of Romans 5-8? Does it work to read 1:16-17; 3:21-26 as presaging chapters $5-8$ ? Or are chapters $5-8$ building upon and advancing beyond chapters $1-4$ ?

\section{Theology}

Here we briefly consider only three of the many theological claims of TDoG.

\subsection{Epistemology}

Having repeatedly indicted J-theory's epistemology as rationalist and prospective, Campbell at the end discloses that 'the signifier "apocalyptic" [is] really just emphasising [a particular] epistemological stance, that is, the fundamentally "revealed" nature of Christian knowledge' (927). Campbell is correct in identifying a rationalist epistemology as foreign to Paul, but does his epistemology fare any better?

Through $T D o G$ the nature of non-Christian knowledge remains deeply ambiguous and, if he is consistent, impossible: what does YHWH's creation reveal about its Creator and about humanity? Campbell confidently replies, 'Nothing', and breathes a sigh of relief. Yet how can this be consistent with another of his (correct) 
epistemological claims-i.e. that 'information is not separable from relationality' (927)? If these two claims - the impossibility of any kind of natural/general revelation and the fundamentally relational nature of knowledge-are to be reconciled, he must insist that the Creator has absolutely no relationship with the non-Christian. Yet Romans 5-8, viewed by Campbell as the purest expression of Paul, speaks of the non-Christian as having a relationship—s/he is an 'enemy' (5:10; cf. 8:7). But how can one be 'hostile' ('́x $(\theta \rho \circ \varsigma)$ and yet have no relationship, being completely ignorant of God? Such a nonrelationship between God and unregenerate humanity also undermines Campbell's basic 'monarchical' and 'benevolent' conception of Paul's God as 'delivering' his creation. Here, then, we find one of Campbell's fundamental theological problems: his doctrine of creation is deficient. In truth, Paul's Scriptures portray the Creator as necessarily in relation with his creation: axiomatically, to create is to own-i.e. to have Ł̇Govoía over that which is fashioned, a concept which Paul himself readily employs (Rom. 9:21; cf. 4:17); and of course Paul's Scriptures attest to an explicit relationship between YHWH and his creation: Genesis 9; Psalms 19, 104, 145; cf. Acts 17:24). Hence, for Paul, to be created is necessarily to be in relation with the Creator and, therefore, necessarily to know. But for Campbell, humans can only have knowledge about God, self, the other, etc., within God's re-creation, whereas in the original creation, knowledge of such things is not possible, or at the very least ambiguous.

The soteriological and missiological implications of this are dire and, it seems, unavoidable. The resulting soteriology is not restorational but quasi-gnostic: only persons who have mysteriously or 'apocalyptically' received 'knowledge' can know; the rest are outside, ignorant. This leads to a critical set of questions: Does Campbell lay a suitable epistemological foundation for Paul's (and the later church's) apostolic mission? Campbell asserts (rightly) that apostolic 'messengers and their message ... mediate the process, but do not cause it or exhaust it' (819, his italics). And yet I could not find in TDoG any explanation of how in epistemological terms such a message could be mediated from messenger to the audience. To answer 'by the Spirit' is, of course, true, but obviously inadequate: what epistemological role does the messenger's proclamation play in the process? What common epistemological ground do messenger and auditor share? Campbell does not provide an answer, perhaps because he is unaware of the 
problem (evident from p. 162, where he is rightly aware that an Anknüpfungspunkt, or 'point of contact' must be made yet completely unaware that one cannot just be made ex nihilo; cf. n. 103 there). Campbell states, 'Converts are, in effect, shifted to the new, Christian state in an event of grace-the apocalyptic moment of revelation' (903). But we never learn just how this happens. Again, Campbell is aware of the necessity of what he calls 'the rhetorical (i.e. persuasive) manipulation of an [unbelieving] audience's presuppositions' (162), but the reader never learns how, in epistemological terms, this is possible. The missiological and ecclesiastical implications of this are obvious and devastating. (This critique, let it be said, is by no means a counter-argument for the rationalist 'prospective' epistemology that Campbell attacks. There are epistemologies available other than a rationalist.)

Also, Campbell's 'prospective vs retrospective' antithesis illuminates but also obscures. What he describes as 'prospective' can more accurately, if crudely, be characterised as a modernist epistemology that assumes the possibility of knowledge apart from God and, when adopted by Christian evangelists, serves terribly as an epistemological vehicle for mission (as well as a basis for the legitimisation of agendas altogether sinister). The term 'retrospective' is perhaps most helpful if one assumes a quasi-Barthian epistemology. Otherwise one can easily hold to a soteriology of unconditional grace in which divine revelation in Christ by the Spirit does not disclose humanity's true condition in toto as much as it brings overwhelming, paradigm-shifting coherence to what had previously been real but deeply conflicted, suppressed, and misused knowledge of self (as well as of God, other, etc.).

\subsection{Theology}

Perhaps the most significant theological issue in TDoG is theology proper, especially the nature of divine justice. Throughout Campbell sets forth a stark contrast between J-theory's 'God of retributive justice' (cf. 88) and (Paul's) apocalyptic, 'inherently benevolent', Trinitarian God.

Within Romans itself Campbell's theology faces obstacles, which he addresses (cf. 89-94) but in a way that introduces tension, if not contradiction, in Paul. Admitting that texts like Romans 4:15; 5:9; 9:22; 12:19; 13:4; 1 Thessalonians 2:14-16 (and Eph. 2:3, 5:6; Col. 3:6, 
which he views as germane) indicate that divine wrath is part of Paul's eschatological vision, he views 'the more [soteriologically] universalistic tendencies apparent in Paul' as 'run[ning] counter to his gloomier vision of the eschaton' (94). These two opposing eschatological visions, then, 'indicate some ambivalence on Paul's part about these future events ... Paul's thinking at this point is not unalloyed' (94). But what Campbell calls 'ambivalence' on such a significant matter as eschatological judgement others might call contradiction. Hence, Campbell's radical antithesis between J-theory theology and his own comes at the price of risking incoherence in the apostle's thought.

But, despite his admissions, does Campbell sufficiently weigh the evidence within Romans itself? In 9:14-23 Paul speaks of God choosing to demonstrate his wrath in order to make his power and glory known; he even speaks of 'vessels of wrath' (v. 22). In 12:19 Paul instructs the Romans that in their everyday relationships they are to keep in mind that “"Vengeance is mine, I will repay", says the Lord'. Indeed, Romans arguably alludes to the heavily retributive Deuteronomy 32 four times (9:14?; 10:19; 12:19; 15:10), and the most explicit citations (Deut. 32:21 in 10:19 and 32:35 in 12:19) explicitly concern divine retribution.

Toward the end he addresses 'The Wrath of God' and he states, 'Anger can be the reflex of benevolence or love ... And, as such, it can be a response to a prior initiative and its repudiation, and, hence, function in a secondary position'. (930). He then states various Pauline texts (e.g. 1 Thess. 1:10; 2:16; 5:3, 9; cf. Eph. 2:1-3; Col. 3:6; 2 Thess. $1: 6-10 ; 2: 2-12$ ) that 'none of these texts explicitly places the wrath of God in a prior location; all are comprehensible as God's reaction against a sinful situation and hence conceivably understandable as part of an account of divine benevolence' (930). But has not Campbell, unwittingly, just summarised Romans 1:18-32, which portrays divine wrath as functioning 'in a secondary position'i.e. as 'God's reaction against a sinful situation'? For divine wrath is disclosed in response to a prior display of divine self-revelation: 'what is able to be known about God is manifest to them, because God has manifested' - when and how? - 'from and through the creation of the world'. This points, once again, to a fundamental problem in Campbell's work: Paul's God is manifest as 'benevolent' in and only in the revelation of Christ. Apart from that revelation, does humanity 
have reason to suspect that God is in any way benevolent? Creation offers no word on the matter of divine benevolence. In truth, Paul affirms the goodness of the creation and God's claim upon it (1 Cor. 8:1-10; 10:25-26; cf. 1 Tim. 4:1-5).

All this aside, Campbell raises critically important questions for the ways in which modernity, with its individualistic and heavily contractual and mercantile staples, has influenced the diet of Pauline scholarship. And yet at times it is hard to escape the conclusion that Campbell is objecting to the idea that God might treat humans fairly. For Campbell, Paul's God must deal with humanity unfairly, even if Paul does seem to mumble something about future eschatological wrath on occasion (e.g. Rom. 5:9) — but on what basis will it be administered?

To my knowledge, nowhere in TDoG does Campbell intimate an alternative conception of divine justice in which individual human actions have significance and are worthy of receiving either positive or negative consequences before God. He grants that they probably are but does not say how or why. At the book's end this ambiguity remains. With respect to Ephesians 2:1-3, he writes, 'the situation underlying God's displeasure is one for which humanity is not held fully (i.e. 'strongly') accountable (although neither is humanity without accountability)' (930). What does this mean? And so his apocalyptic reading accounts well, of course, for aspects of Romans 5-8 (e.g. the 'powers') but it ignores the individualist (but not individualistic) aspects of Romans' anthropology (e.g. catena from the Psalms in ch. 3: 'no, not one'), its eschatology ('So then each of us will give an account of himself to God' [14:12; Paul here is speaking of Christians, but it appeals to a principle derived from Isa. 45:23, in which all humanity is in view]), and its paraenesis (e.g. 'The faith/belief that you have, keep to yourself before God' [14:22]).

\subsection{Scripture}

In Campbell's work the church's doctrine of Scripture takes a massive hit. The hermeneutical key to Romans (or, at least, to chapters 1-4), i.e. the identification of the opposing Teacher's voice, can only be affirmed in retrospect: 'this retrospective judgment is an accident of the text's canonical preservation, of the resulting loss of its original performed content ... We will realize belatedly what the Roman auditors could recognize relatively quickly' (530; cf. 541). With two millennia of church history in the rearview mirror, is 'belatedly' the right word? Out 


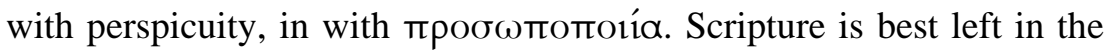
hands of those with an ear to hear the 'voices' in Paul.

\section{Conclusion}

TDoG posits a most provocative thesis. Campbell almost certainly challenges all students of Paul to think in radically new and challenging ways about critical aspects of the apostle's thought. He forces the reader to the Greek text with penetrating questions, fresh construals, and invites us to new vistas of interpretative possibility, with keen argumentative skill, even if that skill occasionally gets in the way of his thesis.

What is the origin of Campbell's most original reading of Paul? Here the book's preface is important. And we only note here that in Part II, entitled, 'Some Hermeneutical Clarifications', he rightly states, 'We must consider the possibility that central commitments within an interpreter's ideology and culture could legitimize central aspects of an explanatory reading' (233). Indeed. Campbell regularly makes the charge of epistemological and theological foundationalism against his opponents, and, to an extent, this is certainly fair. However, if the implication of this charge is that one can be foundationless or presuppositionless, then the charge itself betrays a healthy modernist epistemology, persuaded of its own objectivity. I think Campbell would agree. Better to lay one's foundation (be it divine revelation or otherwise) provisionally and publicly in the hope that others might offer constructive critique. Otherwise one's own 'citadel' of Pauline justification may prove all too pregnable.

In the wake of $T D o G$, who are winners and losers? Perhaps the real winner is Räisänen. If one concedes that Campbell has (1) accurately portrayed traditional readings, (2) overthrown these and yet (3) unsuccessfully offered an alternative (as our exegetical critique might suggest), then, as he himself states, the result is Räisänen's contradictory Paul. Regardless, the losers are at least four in number: (1) fortunately, a modernist/rationalist epistemology; (2) sadly, individual human action; for $T D o G$ is distinctly modernistic in its antithesis of the community and the individual; and the possibility and nature of individual responsibility are ambiguous; (3) again, sadly, the perspicuity of Scripture, as just mentioned; and (4) theology proper, as 
divine autonomy is dealt a serious blow: Campbell presents the reader with a God whose righteousness requires that he save an enslaved humanity, but, alas, he is apparently unable to do so, at least not in toto; some, inexplicably, remain enslaved.

Though Campbell would no doubt disagree, in some sense the great strength of $T D o G$ is that it reveals how disastrous a particular (i.e. a very syncretistic) kind of J-theory can be. But this becomes its great weakness as well. Campbell does not present a J-theory at its best but at its worst, and who wouldn't abandon that for a participationist soteriology? But at the end of the day in a very real sense Campbell can still claim to be Lutheran, for both he and the reformer insist that at/near the heart of Paul's message is the good news that 'God justifies/delivers the ungodly' (669). 